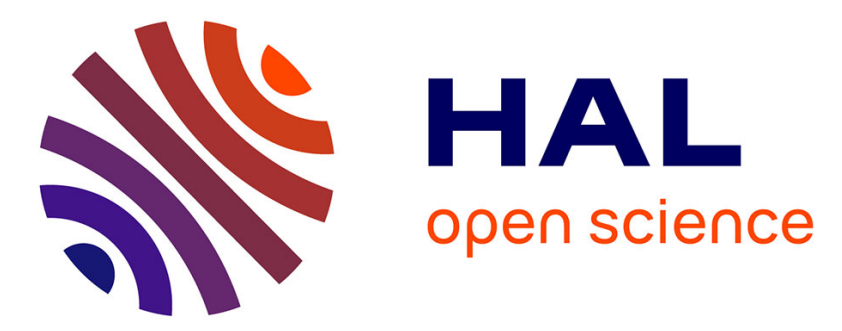

\title{
Ovary growth and protein levels in ovary and fat body during adult-wintering period in the red mason bee, Osmia rufa
}

Oskar Wasielewski, Karol Giejdasz, Tatiana Wojciechowicz, Marek Skrzypski

\section{- To cite this version:}

Oskar Wasielewski, Karol Giejdasz, Tatiana Wojciechowicz, Marek Skrzypski. Ovary growth and protein levels in ovary and fat body during adult-wintering period in the red mason bee, Osmia rufa. Apidologie, 2011, 42 (6), pp.749-758. 10.1007/s13592-011-0084-y · hal-01003622

\section{HAL Id: hal-01003622 \\ https://hal.science/hal-01003622}

Submitted on 1 Jan 2011

HAL is a multi-disciplinary open access archive for the deposit and dissemination of scientific research documents, whether they are published or not. The documents may come from teaching and research institutions in France or abroad, or from public or private research centers.
L'archive ouverte pluridisciplinaire HAL, est destinée au dépôt et à la diffusion de documents scientifiques de niveau recherche, publiés ou non, émanant des établissements d'enseignement et de recherche français ou étrangers, des laboratoires publics ou privés. 


\title{
Ovary growth and protein levels in ovary and fat body during adult-wintering period in the red mason bee, Osmia rufa
}

\author{
Oskar Wasielewski ${ }^{1}$, Karol GIEJDASz $^{1}$, Tatiana WoJciechowicz ${ }^{2}$, Marek SkrZYPSkI ${ }^{2}$ \\ ${ }^{1}$ Institute of Zoology, Poznań University of Life Sciences, Wojska Polskiego 71C, 60-625 Poznań, Poland \\ ${ }^{2}$ Department of Animal Physiology and Biochemistry, Poznań University of Life Sciences, Wojska Polskiego 35, \\ 60-637 Poznań, Poland
}

Received 29 November 2010 - Revised 19 April 2011 - Accepted 26 April 2011

\begin{abstract}
Winter months are supposed to be a crucial period for the development of the reproductive system, especially ovaries, in Osmia rufa females. During 7 months of the wintering period (from September till March), the length and width of terminal oocytes and protein concentrations in ovary and fat body tissue extracts of red mason bee females, $O$. rufa, were studied. Our observations indicate statistically significant differences in the size of terminal oocytes for three different periods of over-wintering: September-October, November-January and February-March. Ovary growth was fast in the September-October period; it slowed down in November-January, and then increased again in February-March. Time-dependent changes were noted also in the number of oocytes and protein concentrations in ovary and fat body tissue during all wintering periods. During all winter months the number of oocytes progressively increased, but a statistically significant increase was only noticed for the periods September-October and February-March. Similarly, during the first two months (September-October) and the last three (February-April) we observed major changes in protein concentration in ovary and fat body tissue. Our results indicate that adult diapause in O. rufa varies to some extent in comparison to the other insects, probably because the the ovary is not fully inhibited during wintering, including the diapause period. These results allow a better understanding of the wintering strategies, including the diapause period, and may be useful for improving rearing methods of this economically important species.
\end{abstract}

\section{diapause / fat body / Osmia rufa / ovary / over-wintering / proteins / solitary bee}

\section{INTRODUCTION}

The red mason bee, Osmia rufa L., is a native European solitary bee showing promise as a manageable pollinator of fruit, especially apples, pears, plums, raspberries and strawberries (Giejdasz and Wilkaniec 2002). Females are not aggressive near their nests, and can be handled safely by the cultivator or beekeepers. However, a more convenient system of housing these bees must be developed to improve nesting success and brood production while

Corresponding author: K. Giejdasz,

kagiede@au.poznan.pl

Manuscript editor: Marla Spivak reducing bee losses due to disease, parasites and overwintering mortality (Wilkaniec and Giejdasz 2003). Basic information on the biology of $O$. rufa, including the development of its successive instars, was obtained as a result of investigations conducted in France (Tasei 1973), Poland (Wójtowski 1979), Germany (Hallmen 1988) and Denmark (Kristjansson 1992). O. rufa was found to be a univoltine species which completes its development from egg to imago in the spring and summer. Under Polish climatic conditions, O. rufa begins its flights in the first 10 days of April and finishes them during the last third of June. At that time, 
the females build nests and lay eggs. The development of the new generation lasts through the summer, and the cocooned adult forms develop in September. O. rufa, like most species of Osmia genus, is an obligatory diapausing species, which overwinters as imago inside a cocoon (Giejdasz and Wilkaniec 2002). Under natural conditions, the bees emerge in the next spring once temperatures rise (Bosch and Kemp 2000).

Day length and temperature regulate diapause in many insects. In some species, diapause is facultative and occurs only when induced by the environmental conditions. In other species, the diapause period has become an obligatory part of the life cycle (Denlinger 2002; Macrae 2005). One of the most common types of diapause in insects is an adult diapause, which involves the arrest of reproductive development, and has been well-characterized in beetles, butterflies, several grasshoppers, and various flies (Tatar and Yin 2001). The shortening of day-length in autumn, or the change from a long- to a short-day photoperiod coupled with the lowering of temperature, is sufficient to induce adult diapause in the Monarch butterfly, (Herman and Tatar 2001), large milkweed bug, Oncopeltus fasciatus (Tatar and Yin 2001), Colorado potato beetle (De Wilde et al. 1968), Musca autumnalis (Krafsur et al. 1999) and several Osmia species (Rust et al. 1989; Bosch and Kemp 2003, 2004; Bosch et al. 2010; Sgolastra et al. 2010). The normal adult diapause is characterized by the ovaries ceasing to develop and by hypertrophy of the fat body (Hondelmann and Poehling 2007). A different situation exists in the genus Osmia. In females, each ovary consists of three pairs of polytrophic ovarioles. In pupae and diapausing adults the number of oocytes per ovariole is four and six respectively. After over-wintering, their numbers increase to a maximum of 11 (Maeta and Kurihara 1971). In pupae and freshly eclosed adults, the germarial region contains oocytes, nurse cells and follicular epithelium cells. In the following months of wintering, the development of oocytes continues progressively in the vitellarium region (Maeta and Kurihara 1971), which implies that the ovaries are not completely inactive during wintering, including the diapause period sensu strictu. Some studies indicate that the oocyte development in $O$. cornuta could even occur while in the cocoon. Moreover, O. cornuta females appear to be capable of developing their oocytes also at low temperatures (Felicioli et al. 2002). Developing oocytes require vitellogenin proteins synthesized and released by the fat body to continue their growth (Maeta and Kurihara 1971). A permanent metabolic activity of fat body directed towards protein synthesis and energy substrate mobilization seems to confirm the gradual depletion of fat body tissue observed in Osmia lignaria (Bosch et al. 2010).

Information concerning the time of diapause initiation, maintenance and termination in the genus Osmia is very scant. Osmia lignaria, a spring-flying solitary bee from North America, enters diapause a few days after adult eclosion. The effective period of diapause maintenance is rather short in this species (Sgolastra et al. 2010). In response to cold temperatures, the respirometry results showed two distinct phases. During the first phase, which lasts $\sim 100$ days, a decrease in the respiratory quotient was observed. In the second phase, O. lignaria females no longer lower their respiration rates (Sgolastra et al. 2010). The first phase would correspond to the period of diapause termination, and the second phase to the period of post-diapause quiescence. This interpretation is consistent with the diapause model proposed by Kostal (2006). Based on this information, diapause in $O$. lignaria would be characterized by an early diapause termination and a long post-diapause quiescence (Sgolastra et al. 2010).

The purpose of the present study was to examine: (a) the start and the end of the diapause period in $O$. rufa, (b) the characterization of ovary growth during over-wintering, and (c) changes between the protein concentration in ovary and fat body tissue during over-wintering, including the diapause period. A good understanding of wintering time, including diapauses, of $O$. rufa is necessary to improve rearing methods and utilization of this species. 


\section{MATERIAL AND METHODS}

\subsection{Bees}

Experiments were conducted in the years 20092010 during the wintering period of Osmia rufa. The experimental material consisted of bees reared in artificial nests made of reed stalks following the method of Wójtowski and Wilkaniec (1978). The experiments started after bees reached adulthood (beginning of September) and were finished in March before the emergence period (Figure 1). During the experiments, bees were reared outdoor in natural conditions, and the temperature was continuously monitored. Nest pipes were dismantled; cocoons were transferred to Petri dishes and dissected, and images were sexed according to morphological characters. For over-wintering experiments we only used females (groups of 30-40 females). The experimental material was collected once in the middle of the month between September and March (ovary growth), and additionally in April (ovary and fat body protein content). From each female, the ovaries and fat body portions were removed for analysis.

\subsection{Ovarian development}

To evaluate the effect of diapause on oocyte growth in $O$. rufa, oocyte size was measured. Decapitated females were submerged in physiological saline, and the ovaries were dissected out under a Stereo Lumar V.12 (Carl Zeiss, Germany) stereoscopic microscope. Length and width of the terminal oocytes were determined using the Axio Vision software for image analysis (Axio Vision software; version 4.8; Carl Zeiss, Germany). The size of the terminal oocyte was measured for each ovariole in the ovary. When determining the number of oocytes in ovarioles, only oocytes with a width of at least $0.1 \mathrm{~mm}$ were considered.

\subsection{Ovarian and fat body protein analysis}

A known quantity of ovary and fat body tissue was homogenized separately in $300 \mu$ of ice-cold saline $\left(130 \mathrm{mM} \mathrm{NaCl}, 1,3 \mathrm{mM} \mathrm{KCl}, 0,9 \mathrm{mM} \mathrm{CaCl}_{2} \cdot 2\right.$ $\mathrm{H}_{2} \mathrm{O}, 1,9 \mathrm{mM} \mathrm{MgCl} 2$ x6 $\mathrm{H}_{2} \mathrm{O}, 2 \mathrm{mM} \mathrm{NaHCO}_{3}$ ). Homogenates were centrifuged at $10,000 \mathrm{~g}$ for $3 \mathrm{~min}$. and supernatants were analyzed for protein content. Protein concentration was assayed using a BCA Protein Assay Kit (Pierce, Rockford, IL, USA) with bovine serum albumin (BSA) as a standard. The assay is based on bicinchoninic acid (BCA) for the colorimetric detection and quantification of total protein (Smith et al. 1985). After incubating samples at $37^{\circ} \mathrm{C}$ for $30 \mathrm{~min}$ in the dark using a Thermomixer comfort (Eppendorf, Germany), the plate was cooled to room temperature and absorbance was measured at $562 \mathrm{~nm}$ using a Synergy2 Multi-Mode Microplate Reader (BioTek Instruments). The protein concentration in the samples were calculated as per $1 \mathrm{mg}$ of tissue.

\subsection{Statistical analysis}

Statistical analyses were conducted using the software package Statistica (Statsoft, V. 9.0). Data were analyzed by one-way ANOVA with Tukey post-

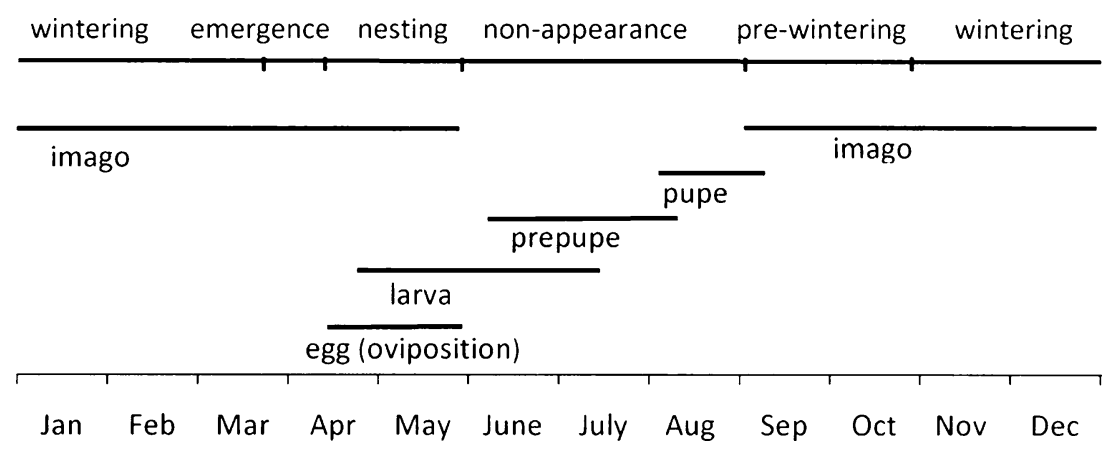

Figure 1. Developmental stages and the adult life cycle of Osmia rufa L. 
hoc tests. In the figures, parameters are presented as means \pm standard deviations.

\section{RESULTS}

\subsection{Ovary development of female $O$. rufa during over-wintering}

At the beginning of September, after bees reached adulthood, the adult wintering period started. In the first period of wintering, from September till October, we observed the dynamic growth of the ovary (Figure 2). In September, just after initiation of wintering, the terminal oocytes were still small, being $0.58 \mathrm{~mm} \pm 0.057$ in length and $0.37 \mathrm{~mm} \pm 0.047$ in width. Moreover, the morphological observations and measurements indicated that the nurse chamber was significantly larger than the oocyte chamber (see Figure 3a). In the middle of October, the first marked growth of the oocytes was noticed. In comparison to their size at the beginning of wintering, oocytes increased by an average of $13 \%$ in(length $(0.65 \mathrm{~mm} \pm 0.057)$ and $22 \%$ in width $(0.45 \mathrm{~mm} \pm 0.040)$, and this increase in size was statistically significant compared with September (Figure 2; $P<0.01$ ). In November, the next relevant increase in terminal oocyte size was recorded. In the successive months, especially in December and January, ovary growth slowed down but did not fully stop (Figure 2). Length and width of oocytes increased over time, as indicated by one-way ANOVA (length: $\mathrm{F}_{6,249}=$ 11.14, $P<0.0001$; width: $\left.\mathrm{F}_{6,249}=9.58, P<0.001\right)$. Tukey post-hoc tests indicated statistically significant growth of terminal oocytes during the first 3 months of the over-wintering period (September-November; $P<0.01$ ). After the oocytes reached $0.7 \mathrm{~mm}$ in size in November, any statistically significant differences $(P>0.05)$ in oocytes size were noticed in the next period of wintering time (December-January) (Figure 2). All of these changes were correlated with outdoor temperature. We observed that the temperature between November and December significantly declined (to $-1^{\circ} \mathrm{C}$ ); the growth rate of terminal oocytes was reduced. During winter months (December-January), measurements did not reveal any apparent differences in size of terminal oocytes, and the ovarian growth was the slowest (Figure 2). In morphology of the ovary, compared with an early period of over-wintering, the size of the nurse chamber was similar to that of the oocyte chamber (Figure 3b).

In February, after the outside temperature rose, a significant increase in oocyte size (length

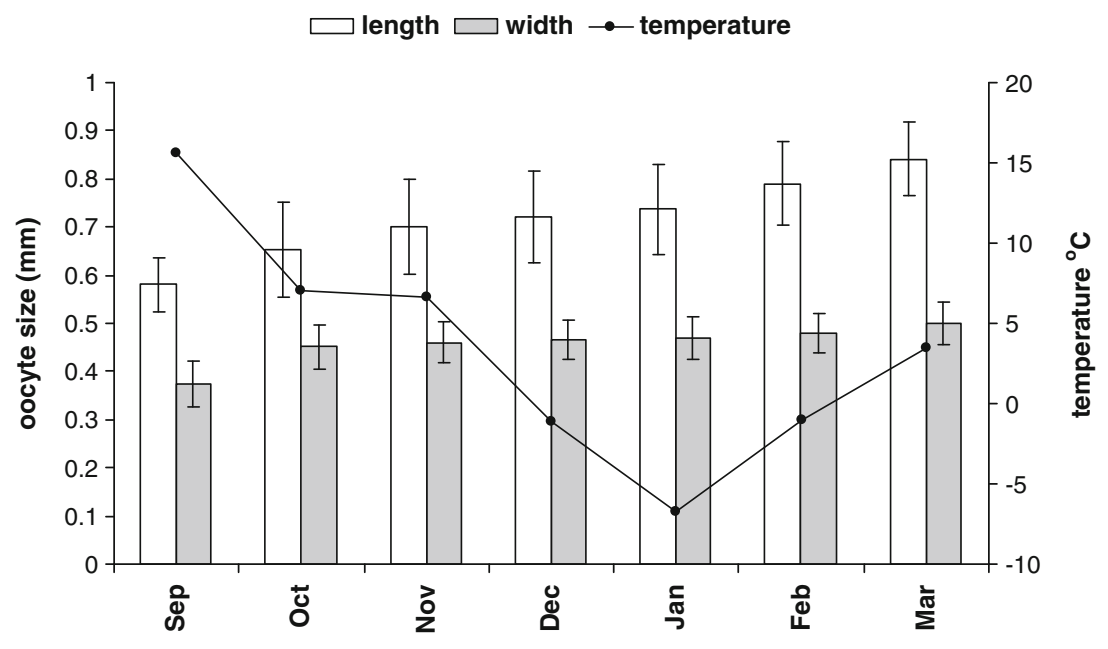

Figure 2. Length and width of terminal oocytes during diapause of female Osmia rufa. Mean values $\pm \mathrm{SD}$ were based on measurement of oocytes from 30 to 40 females. 

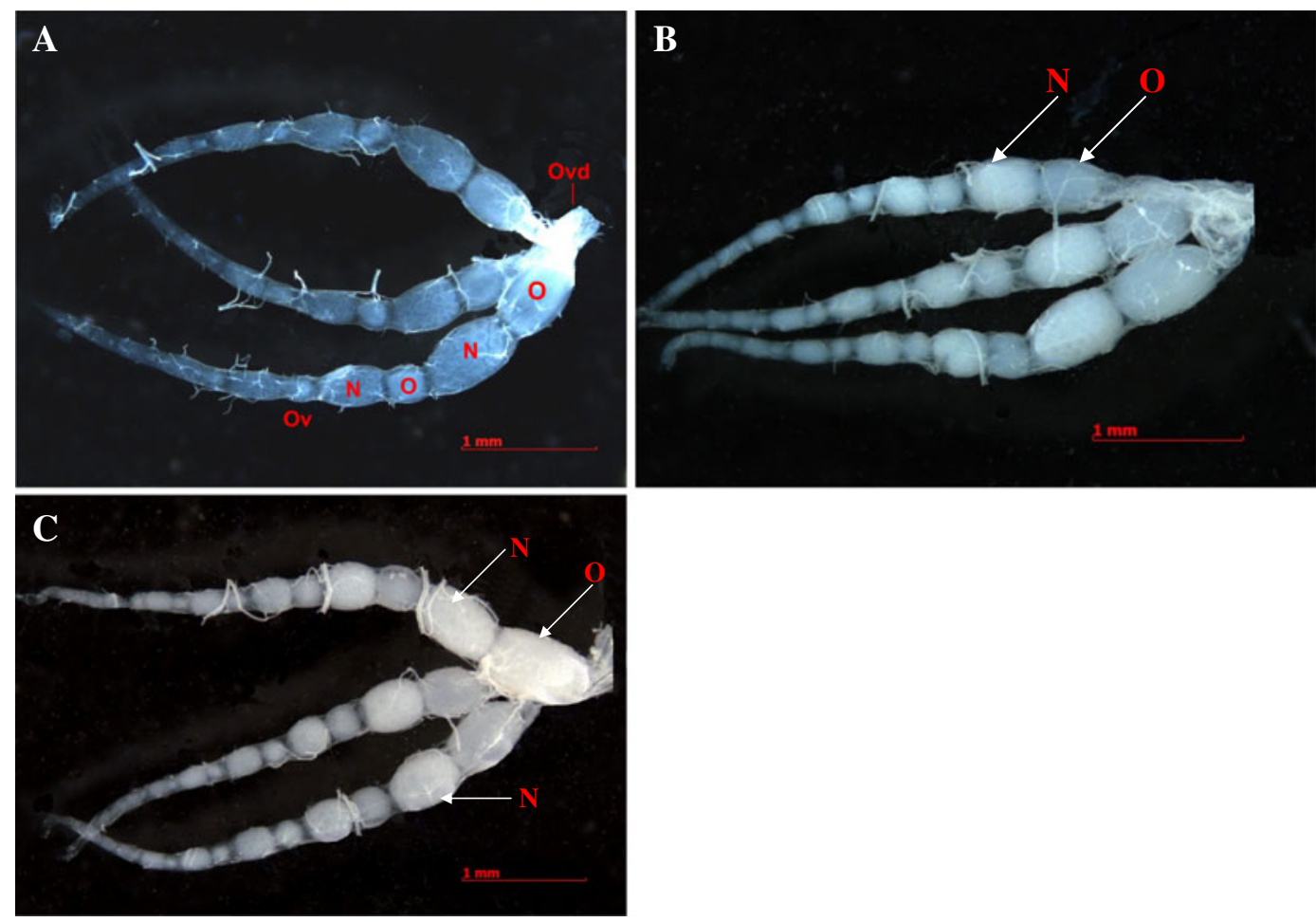

Figure 3. Ovaries isolated from female Osmia rufa at different times of diapause a - September, b - January, c - March. $O v d$ - oviduct, $O v$ - ovariole, $O$ - oocyte, $N$ - nurse cells.

$0.79 \mathrm{~mm} \pm 0.08$; width $0.48 \mathrm{~mm} \pm 0.04)$ was recorded $(P<0.01)$ (Figure 2$)$. In the last month of over-wintering time, in March, just before emergence, the terminal oocytes reached a larger size than in February; their mean length was $0.84 \mathrm{~mm} \pm 0.07$, and width was $0.50 \mathrm{~mm} \pm$ 0.04 (Figure 2). In this period of over-wintering time (February-March), the ovary growth increased again. These changes were accompanied by significantly increase in outdoor temperatures compared to very low temperatures in January (Figure 2). Furthermore, the size of the nurse chamber declined compared to the size of the oocyte chamber, and the nurse cells became indistinguishable in March (Figure 3c). Tukey post-hoc tests indicated statistically significant differences in size of terminal oocytes between three different periods of over-wintering: September-October, November-January, and February-March. The ovary growth was faster in the September-October period $(P<0.01)$, then slowed down in November-January $(P>0.05)$ and then increased again in February-March $(P<0.01)$.

During all months of over-wintering time, the oocytes progressively increased in number (ANOVA $\mathrm{F}_{6,224}=7.34, P<0.001$; Figure 4). Tukey post-hoc tests indicated a statistically significant increase of the oocyte numbers during the first 2 months of over-wintering (September-October; $P<0.01$ ). During this period, the number of oocytes increased from $8.00 \pm$ 0.94 to $8.57 \pm 1.21$. In the next 3 months, November-January, the changes in oocytes numbers were nonsignificant $(P>0.05)$, and fluctuated between 8.70 and 8.88 . We noticed that at the time the ovarian development was clearly slower. During the last period of overwintering time (February-March), the number of oocytes increased in comparison to the two other wintering periods $(P<0.01$; Figure 4$)$. In March, the number of oocytes was $9.88 \pm 1.19$, and was 
Figure 4. Changes in the number of oocytes at different months of diapause in female Osmia rufa ( $n=30$ to 40 females per data point).

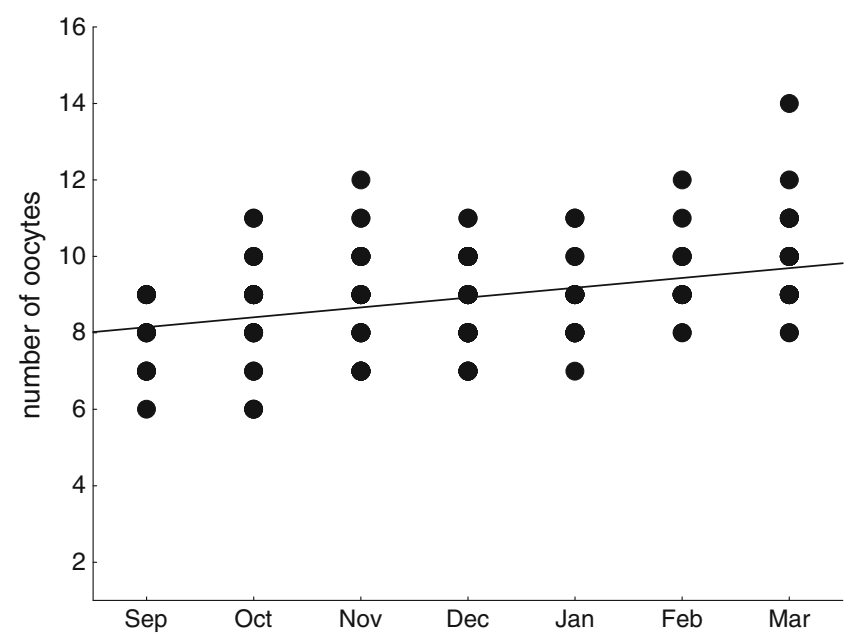

significantly higher that than recorded in September $(8.00 \pm 0.94)$.

\subsection{Ovary and fat body protein concentration during over-wintering}

The amount of total protein in ovary extract at the beginning of over-wintering (in September) of $O$. rufa females was the lowest at $53.39 \pm 6.10 \mu \mathrm{g} / \mathrm{mg}$. In successive months, gradual changes in protein concentration were noticed, as indicated by one wayANOVA $\left(\mathrm{F}_{6,121}=6.46, P<0.001\right)$ (Figure 5). The following month, in October, the first significant increase of proteins concentration was measured (Tukey post-hoc test; $P<0.01$ ). In November, compared to the previous month the protein content $(61.27 \pm 5.25 \mu \mathrm{g} / \mathrm{mg})$ was still similar to that in October $(60.77 \pm 4.03 \mu \mathrm{g} / \mathrm{mg}$; $P>0.05)$. During the next 2 months of wintering time, December-January, the protein concentration rose slightly, but the post-hoc tests did not indicate any significant changes (Tukey post-hoc test; $P>0.05$ ). Furthermore, the notable absence of changes in protein concentration was probably related to the outdoor temperature, which declined in November (Figure 5). The first statistically significant increase was detected in February, as the concentration increased to $78.65 \pm 4.03 \mu \mathrm{g} / \mathrm{mg}$. In the next
2 months, March and April, ovary protein concentration rapidly increased, and before emergence it amounted to $110.26 \pm 7.00 \mu \mathrm{g} / \mathrm{mg}$ (Figure 5). All these changes were correlated with an increase in terminal oocyte size and the rise in temperature.

In contrast to the protein concentration in the ovary, we noted that the protein content in fat body extracts was higher at the beginning of the over-wintering period, amounting to $120.56 \pm 7.40 \mu \mathrm{g} / \mathrm{mg}$ in September. In the consecutive months of wintering time, the protein concentration in fat body extracts decreased, as indicated by one-way ANOVA $\left(\mathrm{F}_{6,112}=3.20, P=0.010\right)$ (Figure 5). The statistically significant decrease in protein concentration was first observed in October (Tukey post-hoc test, $P<0.01$ ). During the next 2 months (November and December) the protein concentration did not change $(P>$ $0.05)$. In January and in the following months, the protein content in fat body tissue decreased, and reached $51.98 \pm 5.76 \mu \mathrm{g} / \mathrm{mg}$ in April $(P<0.01)$ (Figure 5). In comparison with the start of wintering, protein levels in fat body tissue decreased by $57 \%$ at the end of wintering time. Similarly to what was noted for the ovary, changes in the protein content in fat body tissue extracts were associated with temperature (Figure 5). 


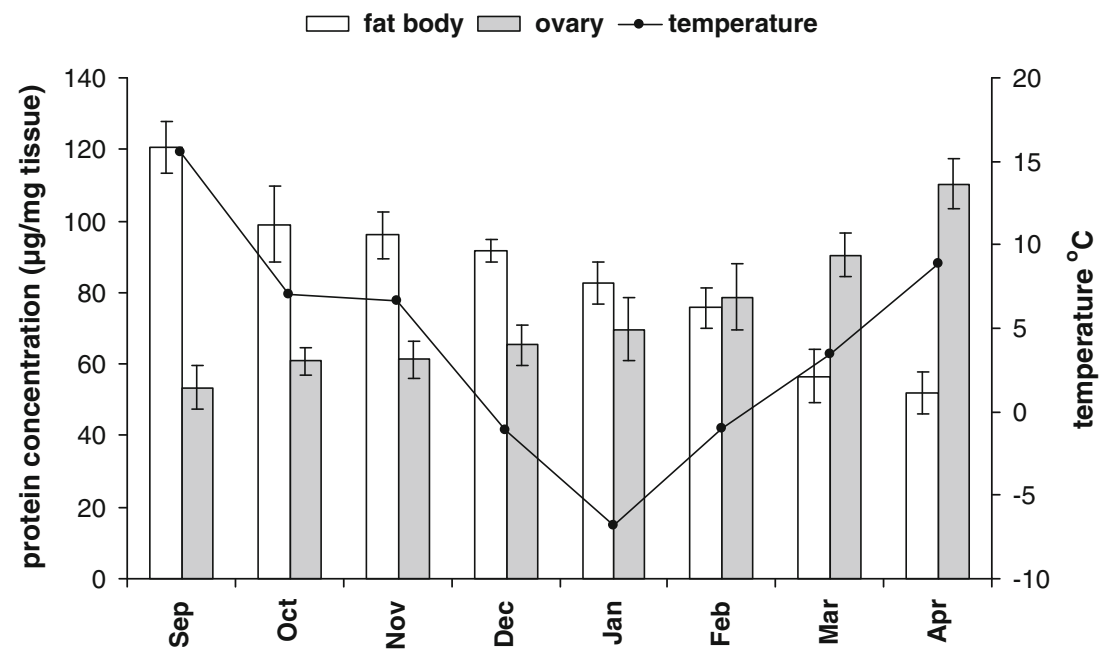

Figure 5. Changes in protein concentration of fat body and ovaries in female Osmia rufa during diapause. Mean values are based on 15 to 20 females; SDs are shown as a two-sided bar.

\section{DISCUSSION}

The pre-wintering period in $O$. rufa females started at the beginning of September, soon after the immatures reached adulthood (Figure 1). A similar situation has been found in other species of the genus Osmia, e.g., in O. lignaria and $O$. cornuta (Bosch and Kemp 2003, 2004; Sgolastra et al. 2010). During the first 2 months of wintering, when the outdoor temperature is still relatively high, we noted that the size of terminal oocytes increased. Our measurements of the average oocyte lengths are slightly different from those reported in Osmia cornuta by Felicioli et al. (2002). O. cornuta is widely distributed throughout the Mediterranean area and southern Europe, and the differences in oocyte size are probably due to different temperatures during ovary growth. The next increase in terminal oocyte size was recorded in November, and was the last before the start of the winter months. Based on our data, October was the last month of the pre-wintering period. In late November, when temperatures declined, ovary growth reached a plateau. During December and January, ovary growth halted, but was not fully arrested. Our observations indicate that $O$. rufa entered diapause in November and finished in January, after the temperature rose. These results are slightly different from other Osmia species. For example, $O$. lignaria started diapause a few days after eclosion, and after a short period of maintenance finished diapause within $\sim 100$ days after adult emergence (Sgolastra et al. 2010). In our study, oocyte size increased in February and March, together with temperature. In our opinion, this time corresponds to a postdiapause quiescence during which low metabolic rates are maintained exogenously, while temperatures are still too cold for morphogenesis (or emergence), and is shorter than in O. lignaria (Sgolastra et al. 2010).

Until now, it has been difficult to construct a model for diapause in $O$. rufa. In this species, diapause is obligate, and occurs in complete darkness. Thus, using the fact that oocyte size could provide a good indicator of morphogenesis resumption in this species, it seems that the most probable model is that of as late diapause termination followed by a short period of postdiapause quiescence. Furthermore, we recorded that in addition to growth, the oocytes progressively increased in number in certain months of over-wintering (Figure 4). We noted that the increase in oocyte number was fast in prewintering months (September-October). In the 
diapause months (November-January) it then slightly fluctuated, and during post-diapause quiescence it increased again. Progressive development of oocytes and an increase in the number of oocytes per ovariole have also been noted in other Osmia species (Maeta and Kurihara 1971). In O. taurus and O. cornifrons, the number of oocytes increased to a maximum of 11 (Maeta and Kurihara 1971) after wintering time, and was thus higher than in O. rufa (9.87) at the same time. The association between size and number of oocytes and respective months in female $O$. rufa indicates that development of oocytes is a gradual process throughout autumn and winter. Moreover, nurse-chamber development shows that ovarian growth in $O$. rufa females is ongoing even in the diapause stage. Our results indicate that, as in other insects with polytrophic ovaries, the nurse chamber is larger than the oocyte chamber in the pre-vitellogenic stage (Heming 2003). In winter months, ovary development slows down but the relative size of the nurse chamber decreases, meaning that the nurse cells are active and transfer material to the oocyte. In the vitellogenic stage, when rapid oocyte enlargement is noted, a shrinkage of the nurse cells is observed (Da Cruz-Landim et al. 2006). We observed a similar process in $O$. rufa females in post-diapause quiescence. It is noteworthy that our results are in contrast to other data (Herman and Tatar 2001; Tatar and Yin 2001; Macrae 2005; Hondelmann and Poehling 2007) which reported that adult reproductive diapause is a process characterized by arrested development of the ovary and oogenesis in females. We conclude that the ovaries of $O$. rufa are not completely inactive during diapause.

Ovary development, especially the size increase of oocytes, is contingent on the synthesis and absorption of vitellogenic proteins, which are synthesized in and released from fat body (Maeta and Kurihara 1971). These vitellogenins accumulate in maturating oocytes, and are generally found in females of various insect species (Nation 2002). In O. rufa females at the beginning of the pre-wintering period, in September, the fat body constitutes the majority of body mass, and fills the entire abdomen. A similar situation was observed by Bosch et al. (2010) in O. lignaria. This phenomenon is linked with the accumulation of metabolic energy substrates from carbohydrates and lipids in fat body tissue (Hahn and Denlinger 2007). In bees reared outdoors, fat body depletion increased with pre-wintering time. In response to fat body depletion, a decrease in protein concentration was observed. The protein content in fat body tissue decreased from September to October, contrasting with the ovaries, where protein content rose at the same time (Figure 5). In the following months (November-January), the protein concentration in both tissues fluctuated, but the changes were not statistically significant. In our opinion, the protein concentration can be another diapause indicator in this species. During post diapause quiescence, the ovary protein concentration increased rapidly, as opposed to the protein content in fat body tissue, which significantly decreased (Figure 5). The changes in protein content in ovary and fat body tissue started after the increase in outdoor temperature. The progressive depletion of fat body may indicate a gradual consumption of metabolic energy substrates accumulated before entry into diapause (Denlinger 2002; Hahn and Denlinger 2007; Bosch et al. 2010). In insects with reproductive diapauses, fat body protein synthesis generally declines significantly (Adams et al. 2002; Tatar and Yin 2001). Furthermore, patterns of fat body protein synthesis change during insect diapause. During adult diapause, especially in females, the fat body synthesizes in different ratios and at all times, both vitellogenic and diapause-related proteins (Arrese and Soulages 2010; Roma et al. 2010). Both types of proteins are present in either photoperiodic situation, as shown for $L$. decemlineata (Dortland 1978), but the relative rate of synthesis for each protein type correlates with photoperiod length and temperature (Dortland and de Kort 1978). It is conceivable that in $O$. rufa females the fat body synthesizes vitellogenic proteins during the over-wintering period, even in diapauses, but at a very low level 
only. A similar situation has been found in other insects with adult diapause (Adams et al. 2002; Denlinger 2002).

Our results demonstrated, for the first time, that changes in ovary morphology and protein concentration in ovary and fat body in female $O$. rufa accompany the pre-wintering and wintering period. The contribution to knowledge of over-wintering time, including the diapause period in Osmia rufa, should improve the management of this bee for crop pollination. The necessity of synchronous adult emergence of a pollinator with the blooming period requires termination of diapause or continuation of the over-wintering period under laboratory conditions. The Red mason bee is used as a managed pollinator in greenhouses and field plots outside its natural flight period from February to July. Thus, our results may be useful in devising methods to control diapause in Osmia rufa, which enables activating adult bees at various times.

\section{ACKNOWLEDGEMENTS}

This study was supported by grant no. N N311 298935 from the Ministry of Science and Higher Education. The authors would like to thank T. H. Sparks and P. Skórka for their constructive criticism and linguistic corrections of this manuscript.

Contract grant sponsor: Grant no. N N311 298935 from Ministry of Science and Higher Education, Poland

Développement ovarien et niveaux de protéines dans l'ovaire et le corps adipeux lors de la période d'hivernage de l'adulte chez Osmia rufa

Diapause / corps adipeux / abeille maçonne / ovaire / hivernage / protéines / abeille solitaire

Ovarwachstum und Proteingehalte im Ovar und Fettkörper während der imaginalen Überwinterungsphase der roten Mauerbiene, Osmia rufa

Diapause / Fettkörper / Osmia rufa / Ovar / Überwinterung / Proteine / solitäre Biene

\section{REFERENCES}

Adams, T.S., Filipi, P.A., Yi, S.X. (2002) Effect of age, diapause and juvenile hormone on oogenesis and the amount of vitellogenin and vitellin in the twospotted stink bug, Perillus bioculatus (Heteroptera: pentatomidae). J. Insect Physiol. 48, 477-486

Arrese, E.L., Soulages, J.L. (2010) Insect fat body: energy, metabolism, and regulation. Annu. Rev. Entomol. 55, 207-225

Bosch, J., Kemp, W.P. (2000) Development and emergence of the orchard pollinator Osmia lignaria (Hymenoptera: Megachilidae). Environ. Entomol. 29, 8-13

Bosch, J., Kemp, W.P. (2003) Effect of wintering duration and temperature on survival and emergence time in males of the orchard pollinator Osmia lignaria (Hymenoptera: Megachilidae). Environ. Entomol. 32, 711-716

Bosch, J., Kemp, W.P. (2004) Effect of pre-wintering and wintering temperature regimes on weight loss, survival and emergence time in mason bee Osmia cornuta (Hymenoptera: Megachilidae). Apidologie 35, 469-479

Bosch, J., Sgolastra, F., Kemp, W.P. (2010) Timing of eclosion affects diapause development, fat body consumption and longevity in Osmia lignaria, a univoltine, adult-wintering solitary bee. J. Insect Physiol. 56, 1949-1957

Da Cruz-Landim, C., Patrício, K., Antonialli Jr., W.F. (2006) Cell death and ovarian development in highly eusocial bees (Hymenoptera, Apidae): caste differentiation and worker egg laying. Braz. J. Morphol. Sci. 23, 27-42

De Wilde, J., Staal, G.B., De Kort, C.A.D., Baard, G. (1968) Juvenile hormone titre in the haemolymph as a function of photoperiodic treatment in the adult Colorado potato beetle (Leptinotarsa decemlineata). Proc. K. Ned. Akad. Wet. C 71, 321-326

Denlinger, D.L. (2002) Regulation of diapause. Annu. Rev. Entomol. 47, 93-122

Dortland, J.F. (1978) Synthesis of vitellogenins and diapause proteins by the fat body of Leptinotarsa, as a function of photoperiod. Physiol. Ent. 3, 281288

Dortland, J.F., de Kort, C.A.D. (1978) Protein synthesis and storage in the aft body of the Colorada potato beetle, Leptinotarsa decemlineata. Insect Biochem. 8, 93-98

Felicioli, A., Kristjanson, K., Lepore, A., Pinzauti, M. (2002) The development of the oocyte in the cocoon imago of Osmia cornuta Latr. (Hymenoptera, Megachilidae): dependence on timing and length of cold treatment. Boll. Lab. Ent. agr. Filippo Silvestri 58, 21-29

Giejdasz, K., Wilkaniec, Z. (2002) Individual development of the red mason bee (Osmia rufa L., 
Megachilidae) under natural and laboratory conditions. J. Apic. Sci 46, 51-57

Hahn, D.A., Denlinger, D.L. (2007) Meeting the energetic demands of insect diapause: nutrient storage and utilization. J. Insect Physiol. 53, 760-773

Hallmen, M. (1988) Die Besiedelung unterschiedlicher künstlicher Nisthilfen durch Osmia rufa L. (Hymenoptera: Megachilidae). Nachr. Ent. Apollo. 9, 199-212

Heming, B.S. (2003) Insect Development and Evolution. Cornell University Press, Ithaca NY

Herman, W.S., Tatar, M. (2001) Juvenile hormone regulation of longevity in the migratory monarch butterfly. Proc. Biol. Sci. 22, 2509-2514

Hondelmann, P., Poehling, H.M. (2007) Diapause and overwintering of the hoverfly Episyrphus balteatus. Entomol. Exp. Appl. 124, 189-200

Kostal, V. (2006) Eco-physiological phases of insect diapause. J. Insect Physiol. 52, 113-127

Krafsur, E.S., Moon, R.D., Kim, Y., Rosales, A.L. (1999) Dynamics of diapause recruitment in populations of the face fly, Musca autumnalis. Med. Vet. Entomol. 13, 337-348

Kristjansson, K. (1992) Development of Solitary Bees as Crop Pollinators, Proceedings of an EC Workshop. Brussels, Belgium, 91-109

Macrae, T.H. (2005) Diapause: diverse states of developmental and metabolic arrest. J. Biol. Res. 3, 3-14

Maeta, Y., Kurihara, M. (1971) Anatomical and histological studies on the oogenesis and oosorption of terminal oocytes within the genus Osmia. Kontyu 39, $138-158$

Nation, J.L. (2002) Insect Physiology and Biochemistry. CRC Press, Boca Raton
Roma, G.C., Bueno, O.C., Camargo-Mathias, M.I. (2010) Morpho-physiological analysis of the insect fat body: a review. Micron 41, 395-401

Rust, R., Torchio, P., Trostle, G. (1989) Late embryogenesis and immature development of Osmia rufa cornigera (Rossi) (Hymenoptera: Megachilidae). Apidologie 20, 359-367

Sgolastra, F., Bosch, J., Molowny-Horas, R., Maini, S., Kemp, W.P. (2010) Effect of temperature regime on diapause intensity in an adult-wintering Hymenopteran with obligate diapause. J. Insect Physiol. 56, 185-194

Smith, P.K., Krohn, R.I., Hermanson, G.T., Mallia, A.K., Gartner, F.H., Provenzano, M.D., Fujimoto, E.K., Goeke, N.M., Olson, B.J., Klenk, D.C. (1985) Measurement of protein using bicinchoninic acid. Anal. Biochem. 150, 76-85

Tasei, J.N. (1973) Le comportement de nidification chez Osmia cornuta Latr. Et Osmia rufa L. (Hymenoptera; Megachilidae). Apidologie 4, 195-225

Tatar, M., Yin, C.M. (2001) Slow aging during insect reproductive diapause: why butterflies, grasshoppers and flies are like worms. Exp. Gerontol. 36, 723-738

Wilkaniec, Z., Giejdasz, K. (2003) Suitability of nesting substrates for cavity-nesting bee Osmia rufa. J. Apic. Res. 42, 29-31

Wójtowski, F. (1979) Observations on the biology and utilization potential of the red mason bee Osmia rufa L. (Apoidea, Megachilidae) (in Polish). Rocz. AR Pozn. 111, 203-208

Wójtowski, F., Wilkaniec, Z. (1978) Rearing and utilization of solitary bees settled in nest traps (in Polish). Instr. Wdroż. AR Pozn. 1, 1-10 